\title{
Allel RET+3 : T a medullary thyroid cancer
}

\author{
A Pławski , M Podralska \\ From Annual Conference on Hereditary Cancers 2009 \\ Szczecin, Poland. 10-11 December 2009
}

In our studies, we compared the frequency of the occurrence of the RET $+3: \mathrm{T}$ allele in our group of 48 medullary thyroid cancer (MTC)patients with the frequency of occurrence of the allele in the Polish population. The frequency of the occurrence of the heterozygote variant of the RET $+3: \mathrm{T}$ for the Polish population reached almost $12 \%(18 / 152)$ of heterozygotes, but in the group of patients with MTC, we did not find even a single RET $+3: T$ allele. The frequency difference is statistically significant and in the Fisher's Exact Test, the two-sided $P$ value is 0.0080 . This observation allows assuming that the occurrence of the RET+3: T in the heterozygotic state may lead to the inhibition of the disease phenotype in the cases of the medullary thyroid carcinoma.

Published: 1 June 2011

doi:10.1186/1897-4287-9-S2-A12

Cite this article as: Pławski and Podralska: Allel RET $+3: T$ a medullary thyroid cancer. Hereditary Cancer in Clinical Practice 2011 9(Suppl 2):A12.

Submit your next manuscript to BioMed Central and take full advantage of:

- Convenient online submission

- Thorough peer review

- No space constraints or color figure charges

- Immediate publication on acceptance

- Inclusion in PubMed, CAS, Scopus and Google Scholar

- Research which is freely available for redistribution

\section{Biomed Central}

